\title{
BOMLASZTÓ INNOVÁCIÓ-E A FELHŐALAPÚ SZOLGÁLTATÁS?
}

A negyedik ipari forradalom részeként, a felhőalapú informatikai szolgáltatások (cloud computing) általánosan elterjedtté váltak az elmúlt évtizedben, jelentős hatással a felhasználói és a szolgáltatói piacra egyaránt. A felhőszolgáltatások által a felhasználók előnyös pénzügyi kondíciókkal új szolgáltatásokhoz és rugalmasabb rendszerekhez jutnak. A szolgáltatók számára az átalakuló informatikai piacon jelentős üzleti növekedési lehetőséget jelentenek a felhőszolgáltatások. Gyors terjedésük miatt az üzleti és tudományos szakirodalomban gyakran bomlasztó (disruptive) innovációként említik a felhőszolgáltatásokat. A szerző vizsgálatában arra keresi a választ, hogy a tudományos szakirodalomban elfogadott, az innováció jellegének megítélésére kidolgozott vizsgálati módszer szerint bomlasztó innováció-e a felhőszolgáltatás. Elemzése során arra a következtetésre jut, hogy a felhőalapú szolgáltatások a vizsgálati modell szerint megfelelnek a bomlasztó innovációval szemben támasztott követelményeknek.

\section{Kulcsszavak: felhőalapú szolgáltatások, fenntartó innováció, bomlasztó innováció, IT, informatikai szolgáltatás}

A felhőalapú szolgáltatások az elmúlt évtizedben jelentősen átalakították az informatika felhasználásának módját és az informatikai szállítók piacát. A felhőszolgáltatások jelentőségét jól mutatja az a tény, hogy 2018 júniusában a világ öt legnagyobb piaci értékü tőzsdére bevezetett vállalata közül mind az öt részben felhőszolgáltatással foglalkozott (CorporateInformation, 2018). A piacra gyakorolt hatása miatt több szerző is bomlasztó innovációnak tartja a felhőszolgáltatásokat. Sultan és van de Bunt-Kokhuis szerint a felhőszolgáltatásokra lehet bomlasztó és fenntartó innovációként is tekinteni (Sultan - van de Bunt-Kokhuis, 2012). DaSilva és társai megfogalmazásában a felhőszolgáltatások 'bomlasztó erővel' rendelkeznek (DaSilva et al., 2013). Surya a szakirodalmi áttekintésében azt találta, hogy bár több szerző is bomlasztó innovációként hivatkozik a felhőszolgáltatásokra, az innováció szempontjából rendkívül kevés elemzés született a témában (Surya et al., 2014).

Cikkünkben egy tudományos vizsgálati modellt használva elemezzük az innováció jellege szerint a felhőszolgáltatásokat. A cikk első részében áttekintjük a bomlasztó innováció szakirodalmát, bemutatjuk a felhőalapú informatikai szolgáltatásokat, ismertetjük a vizsgálati módszert, majd elvégezzük az elemzést.

\section{Irodalmi áttekintés \\ Fenntartó és bomlasztó technológiák}

Az innováció kiemelkedő fontosságú a gazdaság fejlődése szempontjából, így a kutatások egyik fontos tárgya már évtizedek óta. Az innováció 60 különböző meghatározását feldolgozva, Baregheh és társai a következőként definiálták az innovációt: „Az innováció egy több lépcsős folyamat, amely során a szervezetek az ötleteket új vagy továbbfejlesztett termékekké, szolgáltatásokká vagy folyamatokká transzformálják annak érdekében hogy elönyt szerezzenek, versenyezzenek és megkülönböztessék magukat a piacon" (Baregheh et al., 2009, p. 1334.).
Schumpeter volt az egyik első szerző, aki az új technológiák gazdasági növekedésre és fejlődésre gyakorolt hatását vizsgálta (Schumpeter, 1942). Schumpeter szerint a vállalkozók innovációjukkal kreatívan bomlasztják a régi rendszert, és ez a folyamat a piac folyamatos átrendeződését eredményezi. Új vállalatok jelennek meg új technológiai megoldásokkal, amelyek veszélybe sodorják a meglévő vállalatok egy részét.

Évtizedekkel később Christensen értelmezte tovább a bomlasztó technológiák hatását. 1997-ben megjelent könyve a The Innovator's Dilemma (Christensen, 1997) a legújabb kori innovációkutatás alapmüve. A vállalati vezetők innovációs dilemmája abból fakad, hogy azok a logikus és kompetens döntések, amelyeket a menedzsment hoz annak érdekében, hogy a vállalat sikeres maradjon, végül a vállalat piaci pozíciójának elvesztéséhez vezetnek. A dilemma feloldásához Christensen megkülönböztette a fenntartó (sustaining) és a bomlasztó (disruptive) technológiai fejlesztéseket.

Fenntartó technológiai fejlesztések azok, amelyek a termékek teljesítményét és minőségét fokozatosan javítják. A javulás lehet folytonos vagy akár radikális, de a továbbfejlesztett termékek közös jellemzője, hogy olyan területen érnek el javulásokat, amelyek a fösodorbeli vevőknek fontosak. A különböző iparágakban a legtöbb fejlesztés fenntartó jellegü.

A Christensen által definiált fenntartó fejlesztésre jó példát adtak a mobiltelefonok piacán a Nokia készülékei A Nokia a 90-es évek közepétől folyamatosan újabb és újabb modellekkel jelent meg, amelyek egyre jobb és bővebb szolgáltatást nyújtottak, ezzel biztosítva a Nokia helyét a vezető mobiltelefon-gyártók között.

Christensen szerint a fenntartó technológiák a folyamatos fejlesztés eredményeként minőségi és szolgáltatási paramétereikben „túllőnek” a felhasználók igényein, többet nyújtanak, mint amire a vevőknek szükségük van. 


\section{A Christensen modell}

A fenntartó technológiákkal szemben, a bomlasztó technológiai fejlesztések megkülönböztető jellemzője Christensen szerint az, hogy azok általában számos területen alul múlják minőségükben és szolgáltatásukban az aktuálisan piacvezető technológiára épülő termékeket. Azonban a bomlasztó technológiára épülő termékek olyan szolgáltatásokat adnak, vagy olyan jellemzőkkel rendelkeznek, amelyek új értékként jelennek meg a meglévő felhasználók egy rétege, vagy új felhasználók számára. A fejlesztések egyre növekvő kereslet mellett folytatódnak, és így idővel a gyengébb paraméterek terén is megközelítheti vagy túlszárnyalhatja az új technológia a vezető megoldásokat.



1. ábra

A fenntartó és bomlasztó technológiák teljesítménye Forrás: saját szerkesztés Chistensen alapján (Christensen et al., 2015)

Christensen könyvében többek között a tranzisztorokat hozza példaként, mint bomlasztó technológiát a vákuumcsövekkel szemben. Amikor a korabeli rádiókban és más elektronikus eszközökben tranzisztorokat kezdtek használni vákuumcsövek helyett, a hangminőség - ami az egyik legfontosabb paraméter - elmaradt a vákuumcsöves eszközök mögött. Azonban a jelentősen kisebb méret és a jelentősen alacsonyabb energiafogyasztás lehetővé tette hordozható eszközök gyártását, így jöhetett létre a táskarádió, amely átalakította a rádióhallgatási szokásokat. A további fejlesztéseknek köszönhetően, idővel a táskarádiók hangminősége túlszárnyalta a vákuumcsöves termékek minőségét (1. ábra).

A bomlasztó technológián alapuló termékek egyes minőségi paraméterei azonban gyakran később sem érik el a hagyományos termékekét. A már említett Nokia mobiltelefonokat kiszorították az okostelefonok, annak ellenére, hogy például az akkumulátor élettartam szempontjából (amely fontos paraméter a felhasználók számára, hiszen meghatározza, hogy milyen gyakran szükséges feltölteni a telefont) az okostelefonok máig alulmaradnak a hagyományos mobiltelefonokkal szemben.

A bomlasztó technológián alapuló termékek azonban új szolgáltatásokat is nyújtanak és más paraméterekkel rendelkeznek, amiért a felhasználók hajlandók elfogadni egyes paraméterek romlását. Az okostelefonok a telefonálás mellett például internetelérésre és elektronikus levele- zésre is lehetőséget adnak, amiért a felhasználók elfogadják azt, hogy gyakrabban kell feltölteni a készüléket.

A The Innovator's Dilemma után néhány évvel később kiadott, a The Innovator's Solution címü könyvében Christensen kibővítette a bomlasztó technológiák fogalmát termékekre és üzleti modellekre, ezzel bevezetve a bomlasztó innováció fogalmát (Christensen - Raynor, 2003). Definíciója szerint a bomlasztó innováció a piac alsó szegmensében, vagy egy új piaci szegmensben jelenik meg elöször, alacsonyabb árú és gyengébb funkcionalitású termékkel ugyanakkor valamilyen más paraméterben, vagy az üzleti modellben radikálisan újat ajánlva. A fösodorbeli vevők azonban nem váltanak csupán az alacsonyabb ár miatt, minőségi és szolgáltatásbéli elvárásaik miatt továbbra is a hagyományos terméket választják. A bomlasztó innováció csak akkor tud általánossá válni a fő piaci szegmensben, amikor a minőség eléri a fősodorbeli vevők elvárásait. Ekkor ők is hajlandók az új termékre váltani és kihasználni annak alacsonyabb árát. Ebböl a folyamatból következik, hogy a bomlasztó innovációnak árlenyomó hatása van a piacon.

\section{A Christensen modell határai}

Christensen modellje szerint a bomlasztó innováció a piac alsó szegmensében, alacsony árakkal indul. Azonban több olyan jelentős innováció jelent meg Christensen alapmüvének megjelenése óta, amely nem felel meg ennek a definíciónak.

Például a mobiltelefonok megjelenésükkor Christensen modelljének megfelelően valóban alacsonyabb minőséget jelentettek, mint a vezetékes telefonok (rosszabb hangminőség, gyakori sikertelen hívások), azonban az új technológia nem a piac alsó szegmensében, és nem alacsony árakkal jelent meg (Govindarajan - Kopalle, 2006).

A személyfuvarozásban forradalmat okozó Uber szintén nem illeszkedik Christensen modelljébe. Definícióját a gyakorlati életben az Uber személyfuvarozási modelljére alkalmazva Christensen azt találta, hogy az Uber üzleti modellje nem felel meg a bomlasztó innováció definíciójának, mivel indulásakor nem a piac alsó szegmensét, hanem a fösodorbeli vevőket célozta meg, ugyanazokat, akiket a hagyományos taxivállalatok (Christensen et al., 2015).

Ugyanakkor, ha Christensen modelljétől függetlenül az Uber piacra gyakorolt hatását vizsgáljuk, akkor az valódi bomlasztást hajtott végre, és jelentősen átalakította a személyfuvarozási piacot (Kavadias et al., 2016; Smith, 2016) azokban az országokban, ahol nem akadályozták meg adminisztratív eszközökkel a müködését. Az Uber példája rámutat, hogy Christensen bomlasztó innovációs modellje nem tud minden esetet kezelni. Ezt maga Christensen is elismerte, az Ubert „outlier”-nek nevezve a modellje szempontjából (Christensen et al., 2015).

A tudományos modellekkel kapcsolatban nemcsak az az elvárás, hogy utólag modellezzék és magyarázzák az eseményeket, hanem hogy elöre is jelezzék azokat. Christensen modellje az előrejelzés szempontjából használható, azonban nem tökéletes. 2007-ben a Business Week-nek adott interjúja szerint: „A model elörejelzése szerint az 
Apple nem lesz sikeres az iPhone-nal. A történelem egyértelmüen ezt jelzi" (Lepore, 2014). Christensen elörejelzésének hibáját mutatja, hogy az azóta eltelt tíz évben az iPhone az Apple egyik legsikeresebb terméke lett, és az Apple-t a világ egyik legértékesebb vállalatává tette.

Az elörejelzés nehézségével kapcsolatban Tellis arra mutatott rá, hogy nehéz eldönteni egy új technológiáról, ami teljesítményben alul múlja az uralkodó piaci technológiát, hogy végül bomlasztóvá válik-e, vagy egyszerűen csak gyengébb minőséget ad (Tellis, 2006).

A bomlasztó innovációs modellek előrejelző képességét kritizálva Barney azzal érvelt, hogy ,, lehet hogy egyszerüen néhány vállalat szerencsésen választott technológiát” (Barney, 1997).

\section{A Christensen modell kiterjesztései}

Christensen modelljében és az innovációs szakirodalomban a fenntartó és bomlasztó innováció gyakran kategorikusan jelenik meg; egy adott innováció vagy az egyik, vagy a másik kategóriába tartozik. Thommond és Lettice szerint azonban a két véglet (fenntartó és bomlasztó innováció) között folytonos az átmenet, az innovációk ezen a folytonos skálán helyezhetők el (Thomond - Lettice, 2002).

Markides a bomlasztó innovációt Christensentől eltérő kategóriákra osztotta: üzletimodell- és radikális termékinnovációra (Markides, 2006). A két különböző bomlasztó innováció különböző módon jelentkezik, más hatással van a piaci versenyre, és más válaszokat igényel az inkumbensektöl.

Az üzletimodell-innováció nem teremt új termékeket vagy szolgáltatásokat, csupán megváltoztatja a modellt, amivel a végfelhasználóhoz eljut a termék. Markides az Amazon példáját említi; az Amazon nem fedezte fel a könyveladást, csupán megváltoztatta a modellt, ahogy a könyv eljut az ügyfelekhez.

A radikális termékinnováció korábban nem létező termékeket hoz a piacra. Markides többek között a mobiltelefont említi példaként. Érvelése szerint a radikális termékinnováció különbözik a technológiai innovációtól, a mobiltelefon egy új termék és nem egy új technológia (Markides, 2006).

Christensen modelljében a bomlasztó innováció az alsó piacszegmensben jelenik meg, és onnan terjed a piac felső szegmensei felé. Schmidt és Druehl ezt a terjedést vizsgálta, és az alábbi három módszert azonosította a piaci terjedésre: határpiaci terjeszkedés (fringe market encroachment), különálló piaci terjeszkedés (detached market encroachment) és alsó piacszegmensbeli terjeszkedés (lowend market encroachment) (Schmidt - Druehl, 2008).

A határpiaci terjeszkedés egy olyan piacszegmensben jelenik meg elsőként, amelyben a felhasználók igényei részben eltérnek az alsó piacszegmens többi felhasználójától, majd később általánossá válik az alsó, majd a fó piacszegmensekben (Schmidt - Druehl, 2008). A különbséget a Christensen által definiált bomlasztó innováció és a határpiaci innováció között az jelenti, hogy az első esetben az innováció a piac alsó szegmensének egészét célozza, míg a második a piac alsó szegmenséhez tartozó, de attól részben eltérö igényü felhasználókat. A határpiaci innovációra példa Schmidt és Druehl szerint az 5.25" méretü merevlemezek megjelenése a 8 " méretűek után. Az 5.25" merevlemezek tették lehetővé az asztali számítógépek elterjedését, amelyeket a korábbi miniszámítógépekkel megegyező feladatokra használtak.

A különálló piaci innováció egy olyan piacszegmensben jelenik meg elsőként, amelyben a felhasználók igényei alapvetően eltérnek az alsó piacszegmens többi felhasználójától. A különbséget a Christensen által definiált bomlasztó innováció és a különálló piaci innováció között az jelenti, hogy az első esetben az innováció a piac alsó szegmensének egészét célozza, míg a második a piac alsó szegmenséhez tartozó, de attól alapvetően eltérő igényü felhasználókat. A különálló piaci innovációra példa a mobiltelefónia, amely egy új piacot nyitott a hagyományos vezetékes telefonok piaca mellett. A mobiltelefonok ára (mind a készülékek, mind a szolgáltatás esetén) magasabb volt, mint a vezetékes telefonoké, azonban megjelenésekor az új technológia egy új piacot teremtett. Amikor az új technológia elkezdett vevőket elhódítani a hagyományos telefónia piacáról akkor azt az alsó szegmensben tette. Az alacsony előfizetőre jutó bevételt hozó felhasználók mondtak le a vezetékes telefonjukról, a magas bevételt hozó üzleti felhasználók megtartották hagyományos telefonvonalaikat (Schmidt - Druehl, 2008).

Az alsó piacszegmensbeli innováció azonnali hatással van a piac alsó szegmensére. A különbség Christensen bomlasztó innovációja és az alsó piacszegmensbeli innováció között, hogy az első esetben az innováció később beszivárog a többi piacszegmensbe is, míg a második esetben ez nem történik meg. Erre az innovációfajtára példa a diszkont áruházláncok megjelenése az Egyesült Államokban, amelyek nem akarják sem választékban, sem szolgáltatásban felvenni a versenyt a hagyományos elegáns áruházakkal (1. táblázat).

\begin{tabular}{|l|l|l|}
\hline Innováció tipusa & Megjelenés helye & Leírás \\
\hline Fenntartó & Felsö piacszegmens & $\begin{array}{l}\text { A termék elóször a felsö piacszegmensben jelenik meg, } \\
\text { majd lefelé terjeszkedik }\end{array}$ \\
\hline Bomlasztó & Alsó piacszegmens & $\begin{array}{l}\text { A termék elöszzör az alsó piacszegmensben jelenik meg, } \\
\text { majd felfelé terjeszkedik }\end{array}$ \\
\hline Új piaci & Határpiac & $\begin{array}{l}\text { A piac alsó szegmenséhez tartozó, de attól részben eltérő } \\
\text { igényú felhasználókat célozza meg }\end{array}$ \\
\hline Új piaci & Különálló piac & $\begin{array}{l}\text { A piac alsó szegmenséhez tartozó, de attól alapvetöen } \\
\text { eltéroó igényư felhasználókat célozza meg }\end{array}$ \\
\hline $\begin{array}{l}\text { Alsó piac- } \\
\text { szegmensbeli }\end{array}$ & Alsó piacszegmens & $\begin{array}{l}\text { A termék az alsó piacszegmensben jelenik meg, és nem } \\
\text { terjeszkedik más szegmensek felé }\end{array}$ \\
\hline
\end{tabular}

1. táblázat Az innováció megjelenési formái

Forrás: saját szerkesztés Schmidt és Druehl alapján (Schmidt - Druehl, 2008)

\section{Bomlasztó innováció a vállalati informatikában}

A vállalatok és szervezetek által használt információtechnológiai rendszerek (IT) innovációja definiálható számítógépes és kommunikációs rendszerek újszerü alkalmazásaként (Swanson, 1994; Lyytinen - Rose, 2003a). Az IT-innovációnak a számítógépek számítási és adattárolási kapacitásának exponenciális bővülése - Moore törvénye (Waldrop, 2016) - és ennek hatására a számítási kapacitás fajlagos költségének csökkenése adja az alapját.

Egyszerü formában valamennyi IT-innováció egy technológiafejlesztés, amely a hardver vagy szoftver terü- 
leten nyújt újabb szolgáltatást, jobb minőséget, gyorsabb müködést, vagy alacsonyabb költséget. Azonban az IT-innováció gyakran lehetővé tesz szervezeti innovációt, mint például az üzleti folyamatok átdolgozása, vagy a szervezeti struktúra megváltozása (Lyytinen - Rose, 2003b). A vállalati IT-rendszerekhez való távoli hozzáférés (a 90-es években modemen keresztül, később nagysebességü internet elérésen át) csupán egy technikai újítás, azonban lehetővé tette, hogy számos munkakör otthonról is elvégezhető legyen, így hatással van az üzleti folyamatokra és a munkaerő szerkezetére. Az elektronikus levelezésre tekinthetünk úgy, mint egy technikai innovációra, amellyel a hagyományos levelezés papírmentes formában valósul meg, azonban hatása túlmutat a papírhasználat csökkentésén: az email átalakította a vállalati kommunikációt.

Hasonlóan a nem IT-innovációkhoz, az IT-innovációk jelentős része fenntartó jellegü (Lyytinen - Rose, 2003b).

A vállalati IT-rendszerek innovációjának kategorizálására az első modellt Swanson (1994) dolgozta ki, három kategóriát különböztetve meg a 2. táblázat szerint.

\begin{tabular}{|l|l|}
\hline $\begin{array}{l}\text { Az innováció } \\
\text { típusa }\end{array}$ & Az innováció tartalma \\
\hline Típus I & az IT-fejlesztésekkel kapcsolatos innováció \\
\hline Típus II & $\begin{array}{l}\text { az adminisztratív, támogató üzleti } \\
\text { folyamatokkal kapcsolatos innováció } \\
\text { (pl. bérszámfejtés, raktárnyilvántartás) }\end{array}$ \\
\hline Típus III & $\begin{array}{l}\text { az elsődleges üzleti funkciókkal } \\
\text { kapcsolatos innováció } \\
\text { (pl. elektronikus beszerzés, ERP, } \\
\text { beszállítókkal való kapcsolattartás) }\end{array}$ \\
\hline
\end{tabular}

\section{2. táblázat A vállalati IT-rendszerek innovációjának} kategorizálása Swanson szerint

Forrás: saját szerkesztés Swanson alapján (Swanson, 1994, p. 1076.)

Lyytinen és Rose (2003) továbbfejlesztették Swanson háromszintü modelljét arra hivatkozással, hogy az nem ad lehetőséget az alapvető technológiát módosító, bomlasztó innováció felismerésére (Lyytinen - Rose, 2003a). Ezen felül a modern rendszerekben a II. és III. típus nem különül el egyértelműen egymástól, például a raktárnyilvántartás és az elektronikus beszerzés integrált rendszert alkotnak.

A szerzőpáros új modellre tett javaslatot (Lyytinen - Rose, 2003b), egy új innovációs típust, az alapvető ITtechnológiát módosító innovációt (base innovation) hozzáadva a modellhez. Az ebbe a típusba tartozó innováció a többi típusú innovációra is hatással van.

Az új innovációtípus megalkotása mellett összevonták Swanson II. és III. típusú innovációját egy típusba, amelyet szolgáltatási innovációként definiáltak (2. ábra és 3. táblázat).

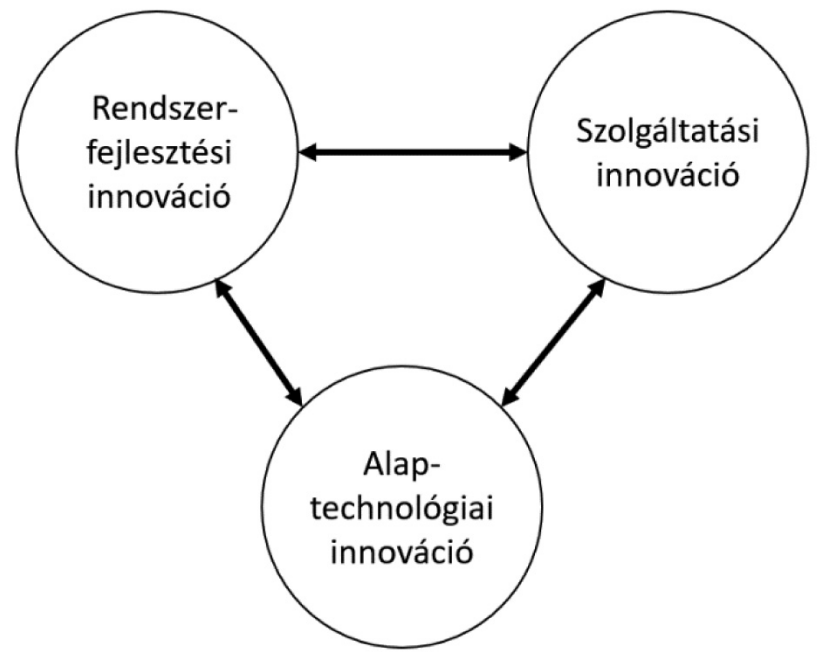

2. ábra

Az IT-innováció fajtái

Forrás: saját szerkesztés Lyytinen és Rose alapján

(Lyytinen - Rose, 2003b)

3. táblázat Az IT-innováció 3 fajtája Lyytinen és Rose alapján

\begin{tabular}{|l|l|}
\hline $\begin{array}{l}\text { Innovációs } \\
\text { kategória }\end{array}$ & Érintett területek \\
\hline $\begin{array}{l}\text { alaptechnológiai } \\
\text { innováció }\end{array}$ & architektúra, alaptechnológia \\
\hline $\begin{array}{l}\text { rendszerfejlesztési } \\
\text { innováció }\end{array}$ & $\begin{array}{l}\text { rendszerfejlesztési folyamatok, } \\
\text { programozási nyelv, adatkezelés }\end{array}$ \\
\hline $\begin{array}{l}\text { szolgáltatási } \\
\text { innováció }\end{array}$ & $\begin{array}{l}\text { adminisztratív és üzleti folyamatok, } \\
\text { gyártás, ügyfélszolgálat }\end{array}$ \\
\hline
\end{tabular}

Forrás: Lyytinen - Rose (2003b)

Az IT-innováció három fajtáját megkülönböztetve, definíciójuk szerint a bomlasztó IT-innováció az architektúrát módosító, az alaptechnológiai szinten keletkező innováció, melynek radikális és szerteágazó hatása van a rendszerfejlesztési folyamatokra és a szolgáltatásokra (Lyytinen - Rose, 2003a; Lyytinen - Rose, 2003b). A radikális és szerteágazó hatás együttesen eredményezi azt, hogy mind a rendszerfejlesztési folyamatok, mind a szolgáltatások területén minőségi változásokat érjen el az innováció.

Lyytinen és Rose modellje alapján Carlo és szerzőtársai megvizsgálták, hogy a három innovációs típus milyen összefüggésben van és hogyan hat egymásra. Kutatásukban a rendszerfejlesztési folyamatokkal kapcsolatos innovációt általánosan folyamatinnovációként definiálták, így cikkükben alaptechnológiai, folyamat- és szolgáltatási innovációs kategóriákat használtak (Carlo et al., 2011). 121 szoftvervállalatot megvizsgálva azt találták, hogy az 
alaptechnológiai innováció közvetlenül és pozitívan befolyásolja a folyamat- és szolgáltatásinnovációt. Továbbá az alaptechnológiai innováció radikalitása közvetlenül és pozitívan hat a szolgáltatási innováció radikalitására.

Például, ha az alaptechnológiai fejlesztés hatására a számítási sebesség/költség arány a tízszeresére javul, az hatással van a fejlesztők által használt folyamatokra és a rendszerek által nyújtott szolgáltatásokra. A 90-es évek mobiltelefonjaiban lévő hardver sebessége nem tette lehetővé videó lejátszását. 15-20 évvel később, a fejlett okostelefonok sokkal gyorsabb hardvere erre lehetőséget adott, így megjelentek az ezt kihasználó videóalkalmazások. Ebben az esetben az alaptechnológiai fejlesztés hatására szolgáltatási innováció történt.

Carlo és szerzőtársai szerint a radikális technológiai innováció általában az alaptechnológiából indul, amit szolgáltatási innováció követ és végül megjelenik a folyamatinnováció (Carlo et al., 2014). Az IT-innováció fajtáit és azok egymásrahatásának módosított modelljét a 3. ábra szemlélteti.



3. ábra

Az IT-innováció fajtái

Forrás: saját szerkesztés Carlo et al. alapján

(Carlo et al., 2014)

\section{A felhőalapú számítástechnika (cloud computing)}

$\mathrm{Az}$ informatikai rendszereket a vállalatok hagyományosan a saját telephelyeiken építették ki, megvásárolva és beüzemelve a szükséges hardver és szoftver eszközöket. Az ilyen hagyományosan telepített rendszerek - a vállalati telephelyre utalva - ,on-premise” vagy „on-prem” elnevezést kaptak (Füzes et al., 2018).

A 2000-es évtized közepén az informatikai rendszerek felhasználásának új módja jelent meg: saját rendszerek kiépítése helyett a felhasználók szolgáltatásként juthatnak informatikai megoldásokhoz (Mell - Grance, 2011; Furht - Escalante, 2010). Mivel a szolgáltatást adó szerverek pontos helye általában nem ismert és nem is fontos a felhasználó számára, a szerverek valahol a „felhőben” vannak - innen ered a felhőalapú számítástechnika elnevezés. Források szerint a „cloud computing” elnevezést először
Eric Schimdt, a Google vezérigazgatója használta egy konferencián tartott előadásban 2006-ban (Sultan - van de Bunt-Kokhuis, 2012).

A felhőmodellben a felhasználók a szolgáltatás előfizetőivé válnak, saját rendszerekbe történő beruházás helyett. A felhőmodell hasonló a villamosenergia-használat ismert modelljéhez: a legtöbb felhasználó nem rendelkezik saját generátorral, nem törődik azzal, hogy hol állítják elő és hogyan vezetik el hozzá az elektromos áramot. Egyszerüen csatlakoztatja a berendezését a konnektorhoz és a fogyasztás után fizet az áramért (Buyya et al., 2010).

A felhőszolgáltatók saját adatközpontokat építenek jelentős beruházási költséggel és az adatközpontokból biztosítják a felhasználók számára a szolgáltatást.

A felhőalapú számítástechnika eltérő szolgáltatásokat foglal magában, amelyek általánosan három fő kategóriára oszthatók (Zissis - Lekkas, 2011; Sultan, 2014):

- infrastruktúra, mint szolgáltatás (infrastructure as a service; IaaS) - a felhőszolgáltatók olyan alapvető infrastrukturális szolgáltatásokat biztosítanak a fogyasztók számára, mint a szerver, tároló vagy számítási kapacitás, és a fogyasztóknak lehetőségük van arra, hogy operációs rendszert, adatbázist és egyéb szoftvereket futtassanak a szolgáltató által biztosított infrastruktúrán,

- platform, mint szolgáltatás (platform as a service; PaaS) - a felhőszolgáltató az infrastruktúra mellett alapvető szoftvermodulokat (operációs rendszer, adatbázis-kezelő, köztes szoftver) biztosít szolgáltatásként a fogyasztó számára, aki ezek segítségével a saját üzleti alkalmazásait tudja futtatni,

- szoftver, mint szolgáltatás (software as a service; SaaS) - a felhőszolgáltató üzleti alkalmazásokat biztosít a felhasználó számára szolgáltatásként (például ERP, HR, toborzás, ügyfélszolgálat, beszerzés).

A felhőalapú szolgáltatások előnyei az informatika onprem modellhez képest (Marston et al., 2011; Chang et al., 2013):

- az előfizetési modell nem igényel jelentős beruházást a felhasználó részéről,

- a szolgáltatás rugalmas, igény esetén gyorsan növelhető vagy csökkenthető a szolgáltatott számítási kapacitás a felhasználó igénye alapján,

- az informatikai rendszerekkel kapcsolatos feladatok jelentős része átkerül a szolgáltatóhoz, így a felhasználó jobban tud a vállalat fö tevékenységére koncentrálni,

- az on-prem rendszerekhez viszonyított nagyobb rugalmasság gyorsabb innovációt tesz lehetővé.

Az előnyök mellett a felhőalapú megoldások veszélyekkel is rendelkeznek, amelyek egy része vélt, más része valós. A felhasználók által a leggyakrabban említett veszélyek a következők (Caldarelli et al., 2017):

- Csökken az adatbiztonság - a felhasználók a legnagyobb veszélynek azt tartják, hogy a felhőben 
nincsenek olyan biztonságban az adatok, mint a saját szervereiken. Tanulmányok szerint ez egy vélt veszély, a valóságban a professzionális felhőszolgáltatók rendszerei nagyobb adatbiztonságot nyújtanak, mint amit a vállalati IT nyújt (IDC, 2016b).

- A kontroll elvesztése a vállalati adatok és rendszerek felett - a kritikus fontosságú vállalati adatok és rendszerek feletti kontroll átkerül egy külső szolgáltatóhoz.

- Jogi akadályok - az országonként változó jogi környezet megtilthatja bizonyos adatok országon kívüli tárolását és feldolgozását. Az Európai Unió a jogi elöírások egységesítésére törekszik. Ennek a törekvésnek jelentős lépése a 2018 májusában EU szinten életbe lépő Általános Adatvédelmi Rendelet, általánosan használt angol rövidítéssel GDPR (European Union, 2018).

- Lassul a rendszerek válaszideje - a felhőben elhelyezett adatokhoz és rendszerekhez való hozzáférés az interneten keresztül történik. Az alacsony internetsebesség lassíthatja az adathozzáférést és a rendszer válaszidejét, az internetkapcsolat megszakadása esetén megszűnhet a hozzáférés. A lassú elérés problémája a ma már általánosan elérhető nagysebességű szélessávú internetkapcsolattal kiküszöbölhető. A kapcsolat megszakadásának veszélyét például duplikált interneteléréssel (két különböző szolgáltatótól) lehet kezelni.

Az elmúlt években a felhőalapú szolgáltatások elterjedté váltak, jelentősen átalakítva a szolgáltatói és felhasználói piacot (Sultan - van de Bunt-Kokhuis, 2012; DaSilva et al., 2013). A felhőszolgáltatásból származó globális bevételek többszörösére növekedtek 2009 óta (Gartner, 2018). Új szolgáltatók jelentek meg a piacon és jelentős üzleteket építettek ki. Néhány vezető felhőszolgáltató: Amazon (Amazon Web Services), Salesforce.com, Workday, Dropbox és Google.

\section{Bomlasztó innováció-e a felhőalapú számítástechnika?}

A felhőalapú számítástechnika az elmúlt évek piaci adatai szerint jelentős hatással van az informatikai szolgáltatások piacára és további növekedés várható (Gartner, 2018). A szakirodalomban több cikk bomlasztó vagy radikális innovációnak tartja a felhőszolgáltatásokat, annak jelentős piaci hatása miatt (Sultan - van de Bunt-Kokhuis, 2012; Susanto et al., 2012; DaSilva et al., 2013; Surya et al., 2014), ugyanakkor, ezek a cikkek nem elemzik a felhőszolgáltatások bomlasztó hatását tudományos modellek alapján.

Ezt a kutatási rést felismerve a következő kutatási kérdés fogalmazható meg: az innovációs szakirodalomban elfogadott vizsgálati módszer szerint bomlasztó innováció-e a felhőszolgáltatás?

A kutatási kérdés megválaszolásával jelen cikk hozzájárul a felhőszolgáltatásokról szóló elméleti szakirodalom bővítéséhez, és segít jobban megérteni a felhőszolgáltatások innovációs jellegét. A felhőszolgáltatások technikai szabványairól, előnyeiről, hátrányairól és elterjedéséről számos tanulmány szól, de ezek alapján nehezen elörejelezhető, hogy a felhőszolgáltatások terjedésének mi a jövőbeli iránya és határa, valamint milyen jövő vár az on-prem rendszerekre. Annak megértése, hogy bomlasztó vagy fenntartó innováció a felhőszolgáltatás, segíthet az elörejelzések kidolgozásában és pontosításában.

\section{Módszertan}

A kutatási kérdés megválaszolására a szakirodalomban elfogadott, a bomlasztó innováció előrejelzésére kidolgozott vizsgálati módszert használjuk. A vizsgálatot a Nagy és társai által kidolgozott három lépcsős általános - nem IT-specifikus - vizsgálati módszerrel végezzük el (Nagy et al., 2016).

\section{Nagy és társai vizsgálati módszere}

Thomond és Lettice három innovációs jellemzőt javasol a bomlasztó innováció felismerésére: radikális funkcionalitás, új technikai szabványok, valamint az innováció tulajdonjoga (Thomond - Lettice, 2002). Thomond és Lettice innovációs jellemzőire alapozva Nagy és társai háromlépcsős modellt alkottak a bomlasztó innováció előrejelzésére (Nagy et al., 2016).

Első lépés annak vizsgálata, hogy az innováció jelente változást radikális funkcionalitás, új technikai szabványok és az innováció tulajdonjoga szempontjából. Modelljük szerint, ha egy innováció a három közül egy vagy több jellemzőben eltér a szervezetek által jelenleg használt innovációitól, akkor az potenciálisan bomlasztó lehet.

Második lépés annak vizsgálata, hogy hol használják az innovációt a szervezet értékláncában. Ennek megértése azért fontos, hogy eldönthető legyen: lényeges hatású-e az innováció a szervezet müködésére?

A harmadik lépés a potenciálisan bomlasztó innováció összehasonlítása az értéklánc ugyanazon helyén jelenleg használt technológiával. Jelentős pozitív változást jelent-e az innováció?

Amennyiben mindhárom kérdésre pozitív válasz adható, úgy az adott innováció potenciálisan bomlasztó hatású lehet.

\section{Az innováció jellegének vizsgálata a Nagy és társai innovációs modell alapján}

\section{Nagy és társai modell - első lépés}

A modell első lépése annak vizsgálata, hogy az innováció jelent-e változást radikális funkcionalitás, új technikai szabványok és az innováció tulajdonjoga szempontjából.

\section{Funkcionalitás}

A felhőalapú számítástechnika felhasználásával a felhasználók hasonló funkciókat érhetnek el szolgáltatásként, mint on-prem rendszerek esetén, azonban a felhőalapú rendszerek további, radikálisan új szolgáltatásokat is képesek nyújtani.

Például a tradicionális ERP-szállítók (SAP, Oracle, Sage, Microsoft) a felhőbe helyezik át rendszereiket, hasonló vagy bővített ERP-szolgáltatást biztosítva (Chen et 
al., 2015; Elragal - Haddara, 2012). Önmagában az ERP on-prem helyett felhőszolgáltatásként való használata még nem jelent radikális funkcióbővítést.

Ugyanakkor, a felhőszolgáltatáson alapuló ERP-rendszerek olyan új funkciókkal is rendelkeznek, amelyeket az on-prem rendszerek nem biztosítottak. Például, a felhasználók mobileszközeikre (tablet, okostelefon) kapnak értesítéseket az ERP-rendszertől és elérik annak funkcióit, így az általuk választott helyszínen és időpontban használhatják a rendszert (Szabó et al., 2013; Oracle, 2018c; SAP, 2018a), ami radikálisan új funkcionalitást jelent számukra. Az on-prem rendszerek is lehetőséget adtak limitált távoli hozzáférésre, azonban korántsem olyan széles funkcionalitással és eszközfüggetlenséggel, mint a felhőalapú ERPrendszerek.

Hasonlóan, az irodai alkalmazások (pl. Word, Excel) felhőszolgáltatásból való igénybevétele önmagában nem jelent új funkcionalitást a végfelhasználó számára, csupán az on-prem rendszereknél megszokott funkciók egyszerübb és rugalmasabb elérését biztosítja. Azonban a felhőszolgáltatás lehetővé tesz olyan csoportmunkát az irodai alkalmazásokkal (például több munkatárs egyszerre dolgozhat ugyanazon a dokumentumon), amelyekre on-prem rendszerek esetén nem volt lehetőség (Skendzic - Kovacic, 2012).

Az adatok felhőben való tárolása radikálisan új funkcionalitást is hoz magával. A Google Docs-on tárolt adatainkat például gyorsan és egyszerüen több eszközről is elérhetjük (munkahelyi és otthoni PC, telefon, tablet), valamint munkatársainkkal megoszthatjuk és velük együtt szerkeszthetjük (Nakayama et al., 2017). Erre az on-prem adattárolás csak limitálva ad lehetőséget.

A csoportmunkát segítő funkcionalitást a Google belső vállalati működésén vizsgálva Sun és társai azt találták, hogy a Google Docs felhőszolgáltatás hatására a vállalati együttmüködés kultúrája nyitottabbá vált (Sun et al., 2014).

A leírt példák alapján megállapíthatjuk, hogy a felhőalapú számítástechnika képes radikálisan új funkcionalitás biztosítására.

\section{Új technikai szabványok}

A felhőalapú szolgáltatások technikai megoldásai jelentősen különböznek az on-prem megoldásoktól, mivel a távoli szolgáltatásnyújtás az on-prem rendszerektől eltérő architekturális és biztonsági megoldásokat igényel. A felhőszolgáltatásokhoz kialakultak az interneten keresztül nyújtott szolgáltatásokra (web services), a virtualizációra, az identitáskezelésre, a biztonságra, a végfelhasználói hozzáférésre és a mobileszközök hozzáférésére vonatkozó szabványok (Rittinghouse - Ransome, 2016).

A felhőszolgáltatók ugyanazon az infrastruktúrán több felhasználót is kiszolgálnak (angol kifejezéssel ,,multitanency") annak érdekében, hogy képesek legyenek kedvezö áron rugalmasan növelni és csökkenteni a szolgáltatást egy adott felhasználó számára. Ez szintén új technikai szabványokat igényel (Tsai et al., 2010).

A felhőszolgáltatások adatvédelmének biztonsága kiemelten fontos terület, ezt az ISO/IEC 27001:2013 (infor- mációbiztonsági irányítási rendszerek követelményszabványa, a tanúsítások alapja) szabvány rögzíti (Orbán, 2015).

A különböző felhőszolgáltatók saját szabványokat is definiálnak. Az eltérő szabványok megnehezítik a különböző felhőszolgáltatások együttműködését, kombinált felhasználását és átjárhatóságát (interoperabilitás). Az eltérő felhőszolgáltatási szabványok egységesítésére több kezdeményezés is született (Lewis, 2012). A technológiai megoldások fejlődésével a felhőszolgáltatásra vonatkozó szabványok folyamatosan bővülnek és fejlődnek (Parasher et al., 2018).

Összefoglalva megállapítható, hogy az on-prem megoldásokhoz képest a felhőalapú számítástechnika új technikai szabványokat használ.

\section{Az innováció tulajdonjoga}

A felhőszolgáltatás nem egy konkrét innováció, amelynek tulajdonjogát bárki birtokolhatná. Az előző fejezetben leírtak alapján a felhőszolgáltatásokat számos müszaki szabvány írja le, amelyek folyamatosan bővülnek (Parasher et al., 2018). Ezeket a publikus szabványokat használva bármely vállalat nyújthat felhőszolgáltatást.

Például Magyarországon a NISZ Nemzeti Infokommunikációs Szolgáltató Zrt. (rövid nevén NISZ Zrt.) felhőszolgáltatást nyújt kormányzati ügyfeleknek, a publikusan elérhető szabványok alapján (NISZ, 2018).

A publikus és több felhőszolgáltató által elfogadott szabványok mellett azonban a felhőszolgáltatók saját megoldásokat is definiálnak és használnak, amelyek innovációs tulajdonjoga a sajátjuk. Az eltérö, saját szabványok használata megnehezíti az interoperabilitást, és a felhasználókat akaratuk ellenére egy adott szolgáltatóhoz kötheti. Ez angol kifejezéssel a ,,vendor lock-in”, amely arra a helyzetre utal, amikor egy adott felhőszolgáltatótól nem vagy csak jelentős költség árán tudja a felhasználó a rendszerét és az adatait átvinni egy másik felhőszolgáltatóhoz (Lewis, 2012).

Például a már említett SAP és Oracle ERP-felhőszolgáltatás, vagy a Word és Excel felhőből való használata olyan egyedi fejlesztésen alapul, melynek tulajdonjoga az adott céghez tartozik.

A felhőszolgáltatásokban a részben publikus, részben saját, nem publikus szabványok használata hasonló az onprem rendszerekhez. Az on-prem rendszerekben is léteznek nyílt szabványok ( $\mathrm{pl}$. Java) sőt, nyílt forráskódú rendszerek (open source) és saját, nem publikus szabványon alapuló megoldások.

A leírtak alapján az innováció tulajdonjoga a felhőszolgáltatások és az on-prem megoldások esetén nem tér el lényegesen.

Nagy és társai modelljének első lépése alapján, a felhőalapú szolgáltatások új technikai szabványokat és új funkcionalitást jelentenek, míg az innováció tulajdonjogában nincs jelentős változás az on-prem rendszerekhez képest. A modell szerint, ha egy innováció a három közül egy vagy több jellemzőben eltér a jelenleg használt innovációtól, akkor az potenciálisan bomlasztó lehet. Ez alapján megállapítjuk, hogy az első lépes alapján a felhőalapú szolgáltatás potenciálisan bomlasztó innováció lehet. 


\section{Nagy és társai modell - második lépés}

A modell második lépése annak vizsgálata, hogy hol használják az innovációt a szervezet értékláncában, vagyis lényeges hatása van-e az innovációnak a szervezet müködésére?

Porter szerint a vállalati értékteremtés lépéseit két csoportra lehet bontani: elsődleges tevékenységekre (bejövő logisztika, termék-előállítás, kimenő logisztika, marketing és értékesítés, szolgáltatások) és támogató tevékenységekre (humánerőforrás-menedzsment, technológiai fejlesztés, beszerzés, vállalati infrastruktúra biztosítása) (Porter - Millar, 1985). Más szerzők részben eltérően csoportosítják a tevékenységeket, de hasonló kategóriákat fogalmaznak meg (Brown, 2008).

Porter modelljét használva megvizsgáljuk, hogy a vállalati értékteremtés elsődleges és támogató tevékenységeit érinti-e a felhőszolgáltatás.

- Bejövő és kimenő logisztika - A logisztika és az ellátási lánc (supply chain) informatikai támogatására - amelyek vállalatirányítási (ERP) rendszer alrendszereinek tekinthetők - a jelentős informatikai szállítók már évek óta rendelkeznek felhőalapú SaaS megoldással, melyek egyre elterjedtebbé válnak (Kasemsap, 2015; Wu et al., 2013; Jun - Wei, 2011; Ten Hompel et al., 2015). Felhőalapú logisztikai megoldást használ például a Philips és a Shell (SAP, 2018c), felhőalapú ERPszolgáltatást az Orange vagy a Bank of America (Oracle, 2018b).

- Termék-elöállítás - A felhőszolgáltatások egyre elterjedtebbé válnak a gyártási tevékenység támogatásában. Az elmúlt években több cikk is rámutatott a felhöszolgáltatások növekvö fontosságára ebben az értékteremtő tevékenységben (Valilai - Houshmand, 2013; Yu et al., 2015; Liu et al., 2017).

- Marketing és értékesítés - A felhőszolgáltatások a marketing és értékesítés vállalati tevékenységét is lefedik, számos felhőszolgáltató ajánl erre a területre SaaS szolgáltatást. A Pat Research felmérésében 13 vezető marketing-felhőszolgáltatást azonosított, mely listát az Adobe, a Salesforce, az Oracle és a HP vezeti. Felhőalapú értékesítési megoldást használ például a T-Mobile, az Adidas (Salesforce, 2018), felhőalapú marketingmegoldást a Piaggio és az FC Bayern München (SAP, 2018d).

- Szolgáltatások (szerviz, ügyfélszolgálat) - Az SAP, Oracle és a Salesforce is kínál SaaS felhőszolgáltatást a szerviz és ügyfélszolgálati feladatokra (SAP, 2018e; Oracle, 2018a; Salesforce, 2018). A vezető szolgáltató mellett számos kisebb cég is ajánl SaaS megoldást erre a területre.

Hasonlóan az elsődleges értékteremtő tevékenységekhez, a vállalati támogató tevékenységek területén is terjednek a felhőalapú megoldások. Az SaaS alapú humánerőforrás-menedzsment megoldások egyre elterjedtebbé válnak, a $\mathrm{BMW}$ és az American Airlines például ilyen megoldást használ (SAP, 2018f). A beszerzést támogató informatikai megoldások is egyre elterjedtebbek felhőalapú szolgáltatásként. Ezen a területen az SAP, Oracle és IBM vezeti az SaaS szolgáltatási piacot (Tasevska, 2017).

Vállalati infrastruktúra - a különböző felhőszolgáltatásokkal kiváltható a vállalati informatikai infrastruktúra hardver elemeinek egy része (pl. szerverek), valamint a szoftver infrastruktúra jelentős része. Az IaaS szolgáltatás magában foglalja az adattárolást, a számítási kapacitást, a biztonsági mentést, a platformszolgáltatást és a szolgáltatásmenedzsmentet. A PaaS szolgáltatás lefedi az adatbázisokat, az üzleti intelligenciát, az integrációs feladatokat, a tesztelési és fejlesztési környezetet, valamint az alkalmazások telepítésének előkészítését. Az SaaS szolgáltatás biztosíthatja - az elözö paragrafusokban ismertetett funkciókon túl - a vállalati tartalom- és dokumentumkezelést, a csoportmunkát, a levelezési és egyéb irodai feladatokat (Liu et al., 2011).

Összefoglalva, az informatika a vállalati értéklánc nem csupán egy meghatározott eleméhez, hanem az egész értéklánchoz kapcsolódik. Egy modern vállalatnál a logisztika, a gyártás, a marketing, az értékesítés, az ügyfélkapcsolatok kezelése, a pénzügyek és az emberierőforrás-menedzsment is informatikai támogatással történik. A mai vállalatok számára az informatika a versenyben maradás elengedhetetlen eszköze (Drótos, 2001; Carr, 2003).

A leírtak alapján az on-prem rendszerek felhőalapú szolgáltatásra váltása közvetlenül hat a vállalati értékteremtés Porter által megfogalmazott elsődleges és támogató tevékenységeire (Porter - Millar, 1985), így lényeges hatással van a teljes vállalat müködésére. Ezzel megállapítással a Nagy és társai modell második lépcsőjének feltétele is teljesül.

\section{Nagy és társai modell - harmadik lépés}

A harmadik lépés a potenciálisan bomlasztó innováció összehasonlítása az értéklánc ugyanazon helyén jelenleg használt technológiával. Jelentős pozitív változást jelent-e az innováció?

A felhöalapú számitástechnika (cloud computing) címü fejezetben összefoglaltuk a felhőalapú számítástechnika előnyeit az on-prem rendszerekhez képest. Az ott leírtak szerint a felhőalapú megoldások jelentős előnyökkel bírnak a felhasználók számára (kedvezőbb cash flow, nagyobb rugalmasság, gyorsabb innováció, a felhasználó számára csökkenő komplexitás). A felhőszolgáltatások gyors terjedése (Gartner, 2018) azt mutatja, hogy a felhasználók jelentős része fontosabbnak értékeli a szolgáltatás előnyeit mint potenciális veszélyeit.

A felsorolt előnyök méréséről és számszerüsítéséről még csak nagyon kevés tudományos cikk született. Piackutatók és tanácsadó cégek viszont publikáltak felméréseket, amelyekben számszerüsítik a felhőszolgáltatások elönyeit.

Az IDC szerint a felhőt használó vállalatok $60 \%$-a az informatikai költségek csökkenését tapasztalta, míg a biztonsági követelményeknek való megfelelés $53 \%$-ánál javult. Az alkalmazottak produktivitása a felmérésben részt vevő vállalatok $50 \%$-ánál javult. Szintén a vállalatok felénél nagyobb lett az üzleti rugalmasság és jobb lett az ügyfélkapcsolatok minősége (IDC, 2017). 
Az IDC tanulmánya szerint a Dropbox csoportmunka megoldása száz felhasználóra számolva \$648.600 üzleti értéket teremt 5 év alatt, miközben 31\%-kal csökkenti a csoportmunkát támogató IT-szervezet időráfordítását (IDC, 2016a).

A McAfee felmérése szerint a felhőszolgáltatást használó vállalatok 18,8\%-a átlagos javulást tapasztalt a folyamatok hatékonyságában, 15,07\% informatikai költségcsökkenést és 19,63\% vállalati növekedést (McAfee, 2018).

A Porter modell szerinti értékteremtő tevékenységeket (Porter - Millar, 1985) egyenként megvizsgálva kimutatható a felhőszolgáltatások pozitív hatása az on-prem technológiával szemben.

Bejövő és kimenő logisztika - Niharika és Ritu szerint a felhőalapú logisztikai megoldások segítenek hatékonnyá és egyszerübbé tenni a globális ellátási láncok müködését. A beszállítókkal, szállítmányozókkal, szállítmányokkal és végfelhasználókkal kapcsolatos információk gyorsabban elérhetők a felhőszolgáltatások által (Niharika Ritu, 2015).

- Termék-előállítás - Xu szerint a felhőszolgáltatások átalakítják a termékek előállítását. A dinamikus skálázhatóság és virtualizált erőforrások felhasználása új lehetőséget jelent a gyártással foglalkozó vállalatok számára (Xu, 2012).

- Marketing és értékesítés - A Forrester piackutató cég felmérésében 306\%-os befektetésarányos megtérülést (ROI) talált egy SAP Marketing Cloud-ot használó ügyfélnél (SAP, 2018b). A Capgemini nemzetközi tanácsadó vállalat egy 295 értékesítési felhőszolgáltatást használó vállalatnál készített tanulmány alapján azt találta, hogy az értékesítés hatékonysága átlagosan 41\%-kal, míg a bevétel 39\%-kal nőtt (Capgemini, 2016).

- Szolgáltatások (szerviz, ügyfélszolgálat) - A CloudRunner felhőszolgáltató és tanácsadó vállalat szerint a felhőszolgáltatások öt kulcsterületen javíthatják az ügyfélszolgálat munkáját: (1) lehetővé teszik, hogy az ügyfelek bármikor, bármilyen eszközről kapcsolatba lépjenek a vállalattal, (2) integrált és teljes körü szolgáltatás nyújtását biztosítják, (3) személyre szabott kiszolgálást nyújtanak, (4) gyors és adekvát ügyfélkezeléssel növelik az ügyfelek bizalmát és (5) teljes kontrollt adnak az ügyfeleknek a vállalattal kapcsolatos ügyeik kezelésében. A Salesforce saját tanulmánya szerint a felhőalapú ügyfélszolgálati megoldásukat használó cégek 32\%-kal nagyobb ügyfél-elégedettséget értek el, mint a piaci átlag (Salesforce, 2018). A Capgemini felmérésében $45 \%$-os ügyfélelégedettség-növekedést tapasztalt a szervíz felhőszolgáltatást használó ügyfelek körében (Capgemini, 2016).

Hasonlóan az elsődleges értékteremtő tevékenységekhez, a vállalati támogató tevékenységekre is pozitív hatással vannak a felhőalapú megoldások. A SaaS alapú humánerőforrás-menedzsment megoldások a Deloitte tanulmánya szerint pozitív hatással vannak a toborzásra, a teljesítménymenedzsmentre és a munkaerő-gazdálkodásra (Deloitte, 2018).

Összességében megállapíthatjuk, hogy a felhőszolgáltatások jelentős pozitív változást jelentenek az on-prem alapú rendszerekhez képest.

A Nagy és társai innovációs modell háromlépcsős vizsgálatának minden lépcsőjére pozitív választ kaptunk, így megállapíthatjuk, hogy a felhőalapú számítástechnika a modell szerint megfelel a bomlasztó innovációval szemben támasztott követelményeknek.

\section{A felhőszolgáltatások és az innovációs modellek}

Christensen szerint a bomlasztó technológiák általában számos területen alul múlják minőségükben és szolgáltatásukban a hagyományos technológiára épülő termékeket, azonban olyan szolgáltatásokat adnak, vagy olyan jellemzőkkel rendelkeznek, amelyek új értékként jelennek meg a meglévő felhasználók egy rétege, vagy új felhasználók számára (Christensen, 1997). A felhőszolgáltatások negatívumaként felsorolt lassuló válaszidő, az adatok feletti kontroll elvesztése és a felmerülő jogi problémák (Caldarelli et al., 2017) tekinthetők úgy, mint a Christensen által leírt „alacsonyabb minőség vagy csökkentett szolgáltatás". Az új jellemzők, amelyek értéket adnak a hagyományos technológiával szemben: a kisebb beruházási igény, a rugalmas szolgáltatás, a gyorsabb innovációs képesség és a vállalati főtevékenységre való koncentrálás lehetősége (Marston et al., 2011; Chang et al., 2013).

Christensen eredeti modellje szerint a bomlasztó innováció a piac alsó szegmensében jelenik meg először és később válik a fösodorbeli vásárlók által elfogadottá. A felhőszolgáltatásokkal kapcsolatosan erről nem állnak rendelkezésre egyértelmü adatok. Több tanulmány is foglalkozik a felhőszolgáltatások elterjedésével a KKV-szektorban (Gupta et al., 2013; Assante et al., 2016), ugyanakkor a korábbi fejezetben felhőszolgáltatás használóként felsorolt T-Mobile, Adidas, Piaggio, BMW és American Airlines nem a piac alsó szegmensét, hanem a fösodort jelenti. Ezek alapján nem egyértelmü, hogy a felhőszolgáltatások terjedése megfelel-e Christensen eredeti modelljének (az alsó piacszegmensből a fösodor felé), vagy a Schmidt és Druehl által leírt (Schmidt - Druehl, 2008) egyéb elterjedési modellnek (határpiaci terjeszkedés, különálló piaci terjeszkedés, alsó piacszegmensbeli terjeszkedés), esetleg egy újabb pályát követ. Ennek a kérdésnek a vizsgálata további empirikus adatok felhasználásával egy következő kutatás tárgya lehet.

A bomlasztó IT-innováció Carlo és szerzőtársai szerint az alaptechnológiából indul, amit szolgáltatási innováció követ és vegül megjelenik a folyamatinnováció (Carlo et al., 2014). A felhőszolgáltatások mint innováció megfelel ennek a folyamatnak: az alaptechológiai fejlesztések (virtualizáció, távoli elérés) lehetővé tették a különböző felhőszolgáltatások (IaaS, PaaS, SaaS) létrejöttét, amelyeket használva a vállalatok átalakítják saját IT-felhasználási folyamataikat. Az alaptechnológiai innováció radikalitása pozitívan hatott a felhőszolgáltatások esetén a szolgáltatási innováció radikalitására, amely megfelel a Carlo és szerzőtársai által leírt folyamatnak (Carlo et al., 2011). 


\section{Összefoglalás}

A felhőalapú számítástechnika piaci sikere mérhető mind a szolgáltató vállalatok üzleti sikerein és pénzügyi eredményén, mind a felhasználók számának növekedésén keresztül. A piaci előrejelzéssel foglalkozó elemzők a felhőszolgáltatások jelentős növekedését prognosztizálják a következő években.

Elemzésünkkel alátámasztottuk, hogy a felhőszolgáltatások új technikai szabványokat és új funkcionalitást hoznak, lényeges hatással vannak a teljes vállalat müködésére, valamint jelentős pozitív változást jelentenek az on-prem alapú rendszerekhez képest. Ezek alapján a felhőszolgáltatások megfelelnek Nagy és társai modelljének bomlasztó innovációval szemben támasztott követelményeinek.

Ugyanakkor vizsgálatunk nem tért ki a felhőszolgáltatások és az on-prem rendszerek potenciális jövőjére. Az innovációs szakirodalom szerint egyes esetekben a bomlasztó és a hagyományos technológia hosszú távon egymás mellett él, más esetekben a bomlasztó technológia kiszorítja a hagyományos technológiát. Az egymás mellett élésre példa a hagyományos és fapados légitársaságok párhuzamos működése; a kiszorításra példa a vákuumcsöves készülékek, vagy a hagyományos telefonok gyártásának megszünése a tranzisztorok és az okostelefonok hatására.

A felhőszolgáltatásoknál és az on-prem technológiánál jelenleg még nyitott a kérdés, hogy a jövőben egymás mellett marad a piacon mindkét technológia, vagy az on-prem rendszerek kiszorulnak. Ez a lényeges kérdés meghatározza majd, hogy a vállalatok hogyan jutnak informatikai szolgáltatásokhoz a jövőben. Ennek elörejelzése - jelen tanulmányunk eredményének felhasználásával - további kutatásra ad lehetőséget.

\section{Felhasznált irodalom}

Assante, D. - Castro, M. - Hamburg, I. - Martin, S. (2016): The Use of Cloud Computing in Smes. Procedia Computer Science, 83, p. 1207-1212. https://doi. org/10.1016/j.procs.2016.04.250

Baregheh, A. - Rowley, J. - Sambrook, S. (2009): Towards a Multidisciplinary Definition of Innovation. Management Decision, 47, p. 1323-1339. https://doi. org/10.1108/00251740910984578

Barney, J. B. (1997): On Flipping Coins and Making Technology Choices: Luck as an Explanation af Technological Foresight and Oversight, Cambridge University Press: Cambridge, UK. https://doi.org/10.1017/ cbo9780511896613.004

Brown, S. P. (2008): Business Processes and Business Functions: A New Way of Looking at Employment. Monthly Labour Review, 131, 51.

Buyya, R. - Broberg, J. - Goscinski, A. M. (2010): Cloud Computing: Principles and Paradigms. Chichester: John Wiley \& Sons

Caldarelli, A. - Ferri, L. - Maffei, M. (2017): Expected Benefits and Perceived Risks of Cloud Computing: An Investigation within an Italian Setting. Technology Analysis \& Strategic Management, 29, p. 167-180. https://doi.org/10.1080/09537325.2016.1210786
Capgemini (2016): What is the ROI for CRM in the Cloud with Salesforce? (Online). Company Website. Available: https:/www.capgemini.com/2016/06/what-is-theroi-for-crm-in-the-cloud-with-salesforce/\# (Accessed 10.03. 2018.)

Carlo, J. L. - Gaskin, J. - Lyytinen, K. - Rose, G. M. (2014): Early vs. Late Adoption of Radical Information Technology Innovations Across Software Development Organizations: An Extension of the Disruptive Information Technology Innovation Model. Information Systems Journal, 24, p. 537-569. https://doi.org/10.1111/isj.12039

Carlo, J. L. - Lyytinen, K. - Rose, G. M. (2011): Internet Computing as a Disruptive Information Technology Innovation: The Role of Strong Order Effects. Information Systems Journal, 21, p. 91-122. https://doi. org/10.1111/j.1365-2575.2009.00345.x

Carr, N. G. (2003): It Doesn't Matter. Educause Review, 38, p. 24-38.

Chang, V. - Walters, R. J. - Wills, G. (2013): The Development that Leads to the Cloud Computing Business Framework. International Journal of Information Management, 33, p. 524-538. https://doi.org/10.1016/j.ijinfomgt.2013.01.005

Chen, C.-S. - Liang, W.-Y. - Hsu, H.-Y. (2015): A Cloud Computing Platform for ERP Applications. Applied Soft Computing, 27, p. 127-136.

Christensen, C. - Raynor, M. E. (2003): The Innovator's Solution: Creating and Sustaining Successful Growth. Boston, Ma.: Harvard Business School Press

Christensen, C. M. (1997): The Innovator's Dilemma: When New Technologies Cause Great Firms To Fail.

Christensen, C. M. - Raynor, M. - Mcdonald, R. (2015): What is Disruptive Innovation? Harvard Business Review, 93, p. 44-53.

Corporateinformation (2018): These Are the Top 100 Companies Ranked by Current Market Capitalization (U.S.\$ Millions) (Online). Available: https://www.corporateinformation.com/top-100.aspx?topcase $=\mathrm{b} \quad$ (Accessed 05.13. 2018)

Dasilva, C. M. - Trkman, P. - Desouza, K. - Lindič, J. (2013): Disruptive Technologies: A Business Model Perspective on Cloud Computing. Technology Analysis \& Strategic Management, 25, p. 1161-1173. https:// doi.org/10.1080/09537325.2013.843661

Deloitte (2018): Cloud HR - Enabling HR Service Delivery (Online). Company Website. Available: https:// www2.deloitte.com/global/en/pages/human-capital/ articles/cloud-hr.html (Accessed 10.03. 2018)

Drótos, Gy. (2001): Az információrendszerek perspektívái. Phd-értekezés.

Elragal, A. - Haddara, M. (2012): The Future of ERP Systems: Look Backward before Moving Forward. Procedia Technology, 5, p. 21-30. https://doi.org/10.1016/j. protcy.2012.09.003

European Union (2018): The EU General Data Protection Regulation (GDPR) (Online). Available: https://www. eugdpr.org/eugdpr.org.html (Accessed 03.05. 2018)

Furht, B. - Escalante, A. (2010): Handbook of Cloud Computing. New York: Springer 
Füzes, P. - Szabó Zs. R. - Gódor, Z. (2018): Szabadulás a kiaknázási csapdából a digitális jővő alakításával. Vezetéstudomány/Budapest Management Review, 49, p. 54-64. https://doi.org/10.14267/veztud.2018.01.06

Gartner (2018): Size of the Public Cloud Computing Services Market from 2009 to 2021 (In Billion U.S. Dollars) (Online). Available: https://www.statista. com/statistics/273818/global-revenue-generated-with-cloud-computing-since-2009/. (Accessed May 5th 2018)

Govindarajan, V. - Kopalle, P. K. (2006): The Usefulness of Measuring Disruptiveness of Innovations Ex Post in Making Ex Ante Predictions. Journal of Product Innovation Management, 23, p. 12-18. https://doi. org/10.1111/j.1540-5885.2005.00176.x

Gupta, P. - Seetharaman, A. - Raj, J. R. (2013): The Usage and Adoption of Cloud Computing by Small and Medium Businesses. International Journal of Information Management, 33, p. 861-874. https://doi.org/10.1016/j. ijinfomgt.2013.07.001

IDC (2016a): The Business Value of Dropbox Business in Supporting Collaboration. Company Website

IDC (2016b): The Fusion of Business and Technology in the Age of Digital Transformation (Online). Online. Available: https://www.oracle.com/webfolder/s/delivery_production/docs/fy16h1/doc34/fb-technology-agedigtrans.pdf (Accessed 03.05. 2018)

IDC (2017): Critical Application and Business KPIS for Successful Cloud Migration. Company Website

Jun, C. - Wei, M. Y. (2011): The Research of Supply Chain Information Collaboration Based on Cloud Computing. Procedia Environmental Sciences, 10, p. 875-880. https://doi.org/10.1016/j.proenv.2011.09.140

Kasemsap, K. (2015): The Role of Cloud Computing in Global Supply Chain. Enterprise Management Strategies in the Era of Cloud Computing. IGI Global. https:// doi.org/10.4018/978-1-4666-9466-8.ch069

Kavadias, S. - Ladas, K. - Loch, C. (2016): The Transformative Business Model. Harvard Business Review, 94, p. 91-98.

Lepore, J. (2014): The Disruption Machine. The New Yorker, 23 , p. 30-36.

Lewis, G. A. (2012): The Role of Standards in CloudComputing Interoperability. Carnegie-Mellon Univ Pittsburgh Pa Software Engineering Inst. https://doi. org/10.21236/ada611213

Liu, F. - Tong, J. - Mao, J. - Bohn, R. - Messina, J. - Badger, L. - Leaf, D. (2011): Nist Cloud Computing Reference Architecture. Nist Special Publication, 500, p. 1-28. https://doi.org/10.6028/nist.sp.500-292

Liu, Y. - Xu, X. - Zhang, L. - Wang, L. - Zhong, R. Y. (2017): Workload-Based Multi-Task Scheduling in Cloud Manufacturing. Robotics and Computer-Integrated Manufacturing, 45, p. 3-20. Https://Doi.Org/10.1016/J. Rcim.2016.09.008

Lyytinen, K. - Rose, G. M. (2003a): Disruptive Information System Innovation: The Case of Internet Computing. Information Systems Journal, 13, p. 301-330. https:// doi.org/10.1046/j.1365-2575.2003.00155.x
Lyytinen, K. - Rose, G. M. (2003b): The Disruptive Nature of Information Technology Innovations: The Case of Internet Computing in Systems Development Organizations. MIS Quarterly, p. 557-596. https://doi. org/10.2307/30036549

Markides, C. (2006): Disruptive Innovation: In Need of Better Theory. Journal of Product Innovation Management, 23, p. 19-25. https://doi.org/10.1111/j.15405885.2005.00177.x

Marston, S. - Li, Z. - Bandyopadhyay, S. - Zhang, J. Ghalsasi, A. (2011): Cloud Computing - The Business Perspective. Decision Support Systems, 51, p. 176-189.

Mcafee (2018): 11 Advantages of Cloud Computing and How Your Business can Benefit from Them (Online). Company Website. Available: https://www.skyhighnetworks.com/cloud-security-blog/11-advantages-ofcloud-computing-and-how-your-business-can-benefitfrom-them/ (Accessed 10.03. 2018)

Mell, P. - Grance, T. (2011): The NIST Definition of Cloud Computing (Recommendations of the National Institute of Standards and Technology-Special Publication 800-145). Washington Dc: NIST. Recuperado De http://csrc.nist.gov/publications/nistpubs/800-145/ sp800-145.pdf. https://doi.org/10.6028/nist.sp.800-145

Nagy, D. - Schuessler, J. - Dubinsky, A. (2016): Defining and Identifying Disruptive Innovations. Industrial Marketing Management, 57, p. 119-126. https://doi. org/10.1016/j.indmarman.2015.11.017

Nakayama, M. - Chen, C. - Taylor, C. W. (2017): The Effects of Perceived Functionality and Usability on Privacy and Security Concerns about Adopting Cloud Applications. Journal of Information Systems Applied Research, 10, 4

Niharika, G. - Ritu, V. (2015): Cloud Architecture for the Logistics Business. Procedia Computer Science, 50, p. 414-420. Https://Doi.Org/10.1016/J.Procs.2015.04.013

NISZ (2018): NISZ szolgáltatások (Online). Company Website. Available: Http://Www.Nisz.Hu/Szolgaltatasok/Informatika (Accessed 10.04. 2018)

Oracle (2018a): Delight Your Customers with Service Cloud (Online). Company Website. Available: Https:// Cloud.Oracle.Com/Service-Cloud (Accessed 10.03. 2018)

Oracle (2018b): Oracle Success Search (Online). Company Website. Available: https://www.oracle.com/search/customers/_/n-p5wf?ntt=erp $\% 20$ cloud $\&$ dy $=1 \& n$ ty $=1 \& n r=112 \& n t k=s 1$

(Accessed 10.03. 2018)

Oracle (2018c): What is Oracle ERP Cloud? (Online). Available: https:/www.oracle.com/applications/erp/ what-is-oracle-erp-cloud.html (Accessed 10.02. 2018)

Orbán, A. (2015): Számítási felhők az e-közigazgatásban - Egy versenyképes technológia. 6. Báthory-Brassai Nemzetközi Konferencia, 2015 Budapest, p.792-800.

Parasher, Y. - Kedia, D. - Singh, P. (2018): Examining Current Standards for Cloud Computing and IoT. Examining Cloud Computing Technologies through the Internet of Things. IGI Global. https://doi.org/10.4018/9781-5225-3445-7.ch006 
Porter, M. E. - Millar, V. E. (1985): How Information Gives You Competitive Advantage. Harvard Business Review Cambridge, Ma.

Rittinghouse, J. W. - Ransome, J. F. (2016): Cloud Computing: Implementation, Management, And Security. CRC Press.

Salesforce (2018): Service Cloud (Online). Company Website. Available: https://www.salesforce.com/products/ service-cloud/overview/ (Accessed 10.03. 2018)

SAP (2018a): Cloud ERP (Online). Available: https://www. sap.com/products/erp/erp-cloud.html (Accessed 10.02. 2018)

SAP (2018b): A Composite Organization Achieved an ROI of 306\% (Online). Available: https://cx.sap.com/en/ gmc29-forrester-tei-marketing?campaigncode $=\mathrm{crm}$ xy17-prg-gmc29_glba\&url_id=text-global-pr (Accessed 10.03. 2018)

SAP (2018c): Customer Testimonials (Online). Company Website. Available: https:/www.sap.com/about/customer-testimonials.html (Accessed 10.03. 2018)

SAP (2018d): Deliver Personalized Brand Experiences with Intelligent Marketing (Online). Company Website. Available: https://www.sap.com/products/crmcommerce/marketing.html (Accessed 10.03. 2018)

SAP (2018e): SAP Service Cloud (Online). Company Website. Available: https://www.sap.com/products/crmservice-cloud-software.html (Accessed 10.03. 2018)

SAP (2018f): SAP Successfactors HCM (Online). Company Website. Available: https://www.successfactors. com/en_us.html (Accessed 10.03. 2018)

Schmidt, G. M. - Druehl, C. T. (2008): When is a Disruptive Innovation Disruptive? Journal of Product Innovation Management, 25, p. 347-369. https://doi.org/10.1111/ j.1540-5885.2008.00306.x

Schumpeter, J. A. (1942): Socialism, Capitalism and Democracy. London: Harper and Brothers

Skendzic, A. - Kovacic, B. (2012): Microsoft Office 365 - Cloud in Business Environment. Mipro, 2012 Proceedings of the 35th International Convention, 2012. IEEE, p. 1434-1439.

Smith, J. W. (2016): The Uber - All Economy of the Future. The Independent Review, 20, p. 383-390.

Sultan, N. (2014): Servitization of the It Industry: The Cloud Phenomenon. Strategic Change, 23, p. 375-388. https://doi.org/10.1002/jsc.1983

Sultan, N. - Van De Bunt-Kokhuis, S. (2012): Organisational Culture and Cloud Computing: Coping with a Disruptive Innovation. Technology Analysis \& Strategic Management, 24, p. 167-179. https://doi.org/10.1080/09 537325.2012.647644

Sun, Y. - Lambert, D. - Uchida, M. - Remy, N. (2014): Collaboration in the Cloud at Google. Proceedings of the 2014 ACM Conference on WEB Science, 2014. ACM, p. 239-240. https://doi.org/10.1145/2615569.2615637

Surya, K. - Mathew, S. - Lehner, F. (2014): Innovation and the Cloud: A Review of Literature. Management of Innovation and Technology (ICMIT), 2014 IEEE International Conference On, 2014. IEEE, p. 193-198. https://doi.org/10.1109/icmit.2014.6942424
Susanto, H. - Almunawar, M. N. - Kang, C. C. (2012): A Review of Cloud Computing Evolution Individual and Business Perspective. https://doi.org/10.2139/ ssrn. 2161693

Swanson, E. B. (19949: Information Systems Innovation among Organizations. Management Science, 40, p. 1069-1092. https://doi.org/10.1287/mnsc.40.9.1069

Szabó, G. - Benczúr, A. - Molnár, B. (2013): ERP-rendszerek a számítási felhőben (Cloud Computing): A felhőtechnikával összefüggő új ERP-kiválasztási kritériumok elemzése. Vezetéstudomány, 44, p. 62-68.

Tasevska, M. (2017): Top 10 Procurement Software Vendors and Market Forecast 2016-2021 (Online). Company Website. Available: https://www.appsruntheworld.com/top-10-procurement-software-vendorsand-market-forecast/ (Accessed 10.03. 2018)

Tellis, G. J. (2006): Disruptive Technology or Visionary Leadership? Journal of Product Innovation Management, 23, p. 34-38. https://doi.org/10.1111/j.15405885.2005.00179.x

Ten Hompel, M. - Rehof, J. - Wolf, O. (2015): Cloud Computing for Logistics. Berlin: Springer

Thomond, P. - Lettice, F. (2002): Disruptive Innovation Explored. Cranfield University, Cranfield, England. Presented at: 9th Ipse International Conference on Concurrent Engineering: Research and Applications (Ce2002)

Tsai, W.-T. - Sun, X. - Balasooriya, J. (2010): Service-Oriented Cloud Computing Architecture. Information Technology: New Generations (ITNG), 2010 Seventh International Conference on, 2010. IEEE, p. 684-689.

Valilai, O. F. - Houshmand, M. (2013): A Collaborative and Integrated Platform to Support Distributed Manufacturing System Using a Service-Oriented Approach Based on Cloud Computing Paradigm. Robotics and Computer-Integrated Manufacturing, 29, p. 110-127. https://doi.org/10.1016/j.rcim.2012.07.009

Waldrop, M. M. (2016): The Chips are Down for Moore's Law. Nature News, 530, p. 144. https://doi. org/10.1038/530144a

Wu, Y. - Cegielski, C. G. - Hazen, B. T. - Hall, D. J. (2013): Cloud Computing in Support of Supply Chain Information System Infrastructure: Understanding When to Go to the Cloud. Journal of Supply Chain Management, 49, p. 25-41. https://doi.org/10.1111/j.1745493x.2012.03287.x

$X u, X$. (2012): From Cloud Computing to Cloud Manufacturing. Robotics and Computer-Integrated Manufacturing, 28, p. 75-86. https://doi.org/10.1016/j. rcim.2011.07.002

$Y u, C$. - Xu, X. - Lu, Y. (2015): Computer-Integrated Manufacturing, Cyber-Physical Systems and Cloud Manufacturing - Concepts and Relationships. Manufacturing Letters, 6, p. 5-9. https://doi.org/10.1016/j. mfglet.2015.11.005

Zissis, D. - Lekkas, D. (2011): Securing E-Government and E-Voting with an Open Cloud Computing Architecture. Government Information Quarterly, 28, p. 239-251. https://doi.org/10.1016/j.giq.2010.05.010 